\title{
Carcass Provisioning to Support Scavengers: Evaluating a Controversial Nature Conservation Practice
}

\author{
Debbie Fielding, Scott Newey, René van der Wal, \\ R. Justin Irvine
}

Received: 22 June 2013/Revised: 9 October 2013/Accepted: 11 November 2013/Published online: 24 December 2013

\begin{abstract}
A number of scavenger species have suffered population declines across Europe. In attempts to reverse their decline, some land and wildlife managers have adopted the practice of leaving or placing out carcasses of wild or domestic herbivores to provide a source of carrion. However, this can be a controversial practice, with as yet unclear outcomes for many target species and the ecosystems they are part of. Here we bring out the key aspects of this increasingly common conservation practice illustrated using three contrasting cases studies. We show that the provision of carcasses is often motivated by a desire to benefit charismatic species or to facilitate nutrient cycling throughout an ecosystem. Evidence for the effectiveness of this practice in achieving these objectives, however, is mostly lacking, with ecologists studying "easier" species groups such as beetles and therefore not providing relevant insights. Moreover, conflicts between environmental policies that carcass provisioning is aimed at and other social and economic objectives do occur but these projects are often designed without taking into account this broader context. We conclude that expecting carcasses to simply be "good for biodiversity" may be too naïve a view. A greater knowledge of the impact of carcass provisioning and placement on ecosystems and society at large is required before it can become a more effective conservation tool at a wider scale.
\end{abstract}

Keywords Beliefs · Biodiversity · Conflict $\cdot$ Economics · Nutrients $\cdot$ Public perception

\section{INTRODUCTION}

Populations of some scavenger species have suffered declines across Europe (Whitfield et al. 2008; Margalida et al. 2010). This can be attributed to a number of causes which include habitat loss and fragmentation (Groom et al. 2006), as well as a reduction in the availability of carrion (Whitfield et al. 2008). The latter can partially be attributed to the loss of top predators from many systems. In near natural systems (such as the Yellowstone National Park and the Bialowieza Primeval Forest), top predators provide a well dispersed and regular supply of partially consumed carcasses to scavengers, resulting in diverse scavenger communities (Wilmers et al. 2003; Selva et al. 2005). However, due to the loss of top predators from most ecosystems this regular supply of carrion is lost. Management of both wild and domestic herbivores in many countries can enhance this problem. For example, wild herbivores such as deer are removed from the environment through either trophy hunting, population control or to provide meat for human consumption, thus few carcasses become available to scavengers from natural mortality (Whitfield et al. 2008; Wilson and Wolkovich 2011). Furthermore, changes in Common Agricultural Policy (CAP) subsidies have led to a reduction in the number of domestic animals kept in the uplands throughout Europe (Scottish Agricultural College 2008), thus further reducing the availability of carrion to scavengers and the decline in carrion availability is exacerbated by changes in legislation relating to livestock health and disease which require any domestic animal that has died to be removed from the land in all but the most remote upland areas (Margalida et al. 2010).

In order to reverse this trend, there has been an increase in the practice of deliberately leaving or placing out carcasses of domestic or wild herbivores with the aim of providing a source of supplementary food for scavengers. This practice has been implemented predominately to benefit avian scavengers in many countries including Europe (Spain, France, and UK) and parts of Africa and 
Asia (Piper 2005; Gilbert et al. 2007; The Scottish Government 2011a; John Muir Trust 2012) but it has also been used to benefit the wider scavenger communities and to promote nutrient cycling (John Muir Trust 2009; Cunningham 2010). However, the benefits of this activity for the target species or the wider consequences for the other trophic levels and ecosystem functions are unclear. In addition, conflicts have arisen between those who provide carcasses for nature conservation reasons and other people in these localities. These conflicts revolve around a number of issues ranging from impacts on local livelihoods due to conflicting land uses to differences in opinion on the acceptability of this practice.

The carcasses of large herbivores represent substantial energy and nutrient inputs into terrestrial food webs and recycling of these organic materials represents a critical process that influences the structure, functioning, and regulation of ecosystems worldwide (DeAngelis 1992; Heinrich 2012). Thus, carcasses of animals that remain in situ provide resources for both vertebrate (Selva et al. 2003; Cortés-Avizanda et al. 2009a) and invertebrate scavengers (Melis et al. 2004), as well as influencing plants and the soil environment (Towne 2000), with potential consequences for local food webs. By contrast, carcasses that are removed represent a loss of energy and nutrients from the system (Wilson and Wolkovich 2011), impacting on scavenger and predator species that may depend on this resource (Margalida et al. 2010). It is within this latter context that the practice of providing carcasses to support scavengers is increasing, supported by the premise that allowing nutrients to be recycled within the local environment benefits biodiversity and ecosystem function.

Although the local ecological effects of carcasses on soils, plants, and invertebrates have been studied (see Towne 2000; Danell et al. 2002; Melis et al. 2004; Melis et al. 2007; Barton et al. 2013a and reviews by DeVault et al. 2003; Carter et al. 2007, and Barton et al. 2013b) the wider implications on the food web as a whole (including vertebrate scavengers) as well as the extent to which the objectives for carcass provisioning are achieved remain largely unexplored. Here, we examine the motivations for and controversies around the practice of leaving carcasses in situ including the reasons why animal carcasses have been removed from their natural habitats in the first place. We present three contrasting case studies to provide insights into different aspects of this practice, namely: the conservation of vultures in South West Europe; re-wilding in the Netherlands; and enhancing scavenger populations and communities in the Scottish Uplands. We use these case studies to illustrate some of the ecological and socioeconomic dimensions of this practice in order to inform the debate on the role of carcass placement in nature conservation. For each case study, we consider the ecological and socio-economic costs and benefits and discuss how the practice can fit in with existing land uses. Finally, we discuss how the current evidence supports the perceived benefits motivating carcass placement across the case studies and identify where knowledge is lacking to evaluate this increasingly common nature conservation practice.

\section{CASE STUDIES}

\section{Case Study 1: Conservation of Vultures in South West Europe}

\section{Background}

Conservation of vultures is a priority in many areas of South West Europe. Historically, in rural areas of Spain and France, carcasses of domestic livestock were often left in situ to avoid costly extraction and disposal from remote or inaccessible areas (Cortés-Avizanda et al. 2010). Vultures in these regions rapidly broke open and removed these carcasses. However, outbreaks of Bovine Spongiform Encephalopathy (BSE) between 1996 and 2000 raised concern that livestock carcasses may spread disease if left in situ, thus the carcasses were considered hazardous to human health (Margalida et al. 2010). In 2002, legislation was introduced which required all carcasses of dead livestock to be removed from farms and incinerated (Regulation (EC) No 1774/2002 2002).

\section{The Issues}

The reduced availability of carcasses was associated with declines in vulture populations, juvenile survival, and an increase in the number of reported vulture attacks on livestock (Margalida et al. 2010, 2011). In addition, carcass disposal became more costly for farmers and the need to transport and incinerate carcasses led to increased carbon emissions (Dupont et al. 2012). Thus a conflict of objectives had arisen between European level public health policies, conservation objectives, and the local environmental, social, and economic objectives. This resulted in a call (by both farmers and conservationists) to reinstate the tradition of leaving and placing out carcasses for vultures. This was the motivation for a dispensation to the sanitary regulations (Regulation 2005/830/EC 2005) whereby vulture feeding stations were established. In this case, carcasses were deposited at these so-called vulture restaurants within fenced areas, so that they were available to birds but mammalian scavengers were excluded (Moreno-Opo et al. 2012). 


\section{Costs and Benefits of Leaving Carcasses}

Ecological Impacts Since the introduction of vulture feeding stations, carcass availability has become much more consistent and predictable in both space and time (Margalida et al. 2010). This had a number of ecological effects. First, large numbers of vultures started to utilize feeding stations, demonstrating no fear toward the individual regularly provisioning the station (Zuberogoitia et al. 2010). Second, the stations were often dominated by one vulture species (i.e., griffon vulture Gyps fulvus), thus excluding smaller avian scavengers of conservation concern (Cortés-Avizanda et al. 2010) and possibly distorting community structure over wide areas given the large home range of the species involved. Third, as well as potential competition arising within the guild of avian scavengers, more local effects such as increased predation of ground nesting birds near feeding stations was recorded (Cortés-Avizanda et al. 2009b). Fourth, there is concern that vulture health may be adversely affected by the consumption of medicated livestock as was shown for Spanish Imperial Eagles Aquila adalberti (Blanco et al. 2011). However, the impact of vulture feeding stations was shown in some cases to be beneficial to non-target species, for example supporting rare carrion feeding invertebrates (Martín-Vega and Baz 2011). In summary, it has generally been recognized that centralized feeding stations promote non-natural behavior in scavengers and have the potential to alter community composition and dynamics. In recognition of these issues, legislative changes were introduced in 2011 which now permit farmers (with permission from state officials) to leave some domestic carcasses in the field as well as at designated feeding stations (Commission regulation (EU) No 142/2011 2011) in order to distribute vulture populations more evenly.

Socio-economic Impacts Where domestic livestock carcasses are left in situ in the wider landscape, as opposed to being collected for incineration or placed at vulture feeding stations, scavenging by vultures has been estimated to generate savings of US\$ 1.2-2.1 million year $^{-1}$ across the $\mathrm{EU}$ as a whole; hence, there is an economic argument for the in situ carcass disposal service provided by vultures (Margalida and Colomer 2012). Also, where feeding stations have been established to attract vultures this has encouraged tourism and prompted the development of viewing platforms (Bird watching Bulgaria 2008; Goosney 2008; Auduin bird tours 2012). However, the placement of carcasses remains highly regulated because of human health concerns despite the socio-economic benefits that have been demonstrated.

\section{Case Study 2: Re-wilding in the Netherlands}

\section{Background}

In the quest for more agricultural land, Dutch engineers drained part of an inland sea in 1968 to create the polder "Zuidelijk Flevoland" (Vera 2009). One corner which remained too wet for further development was transformed through natural succession, into a unique marshland: the Oostvaardersplassen. Its large size ( $\sim 6000 \mathrm{ha})$, remoteness, and impressive number of rare species reaching high local abundance meant that the Oostvaardersplassen became a candidate for re-wilding, i.e., to recreate and restore the ecosystem processes believed to have occurred in such a marsh area in the past (Vera 2009; ICM02 2010). Site management, of notably, the drier parts became based on the principle of minimal human intervention. Because few wild large herbivores were present, domestic cattle, ponies, and red deer were introduced to restore the important grazing functions. This diversified the vegetation in turn benefitting a wide range of animals. However, the need to manage the livestock fell short of re-wilding principles where the aspiration was to allow all animals, both domestic and wild, to live unmanaged and regulated by natural food limitation. As a result, carcasses of both wild herbivores and livestock (by management also seen as wild, a perspective endorsed in court) were left where they fell. This activity is counter to accepted conventions on livestock husbandry which require intervention for sick and dying animals and their removal from a (eco)system and was criticized by members of the public.

\section{Motivations for Leaving Carcasses}

The State Forest Service which governs the management of the Oostvaardersplassen argues that leaving carcasses in situ benefits biodiversity by providing food for scavengers and enabling nutrient cycling within the reserve (Tramper 1999; Staatsbosbeheer 2012). This management practice contributes to the organization's overall objective to develop a natural marsh ecosystem of high conservation value (Staatsbosbeheer 2011).

\section{The Issues}

Because EU carcass disposal regulations (Regulation (EC) No 1774/2002 2002) require carcasses of domestic animals to be removed only wild deer carcasses should be allowed to remain where they fall within the reserve. An exemption to this legislation was made in 1996 allowing carcasses of cattle and ponies to remain in situ within the Oostvaardersplassen. However, farmers, members of the public, and the animal rights movement criticized 
the actions of the reserve managers, for first allowing herbivore populations to increase in an uncontrolled manner leading to significant die-offs (especially in cold winters) and second leaving the carcasses in situ (Van Klink and Kampf 2008). In particular, neighboring farmers were unhappy that this was permitted within the reserve whilst they had to comply with stringent carcass disposal regulations. They further argued that the exemption in the reserve could lead to an increased risk of disease to livestock neighboring the area (Van Klink and Kampf 2005), which could lead to financial loss and potential export restrictions. Therefore, the exemption was withdrawn the following year (Van Leeuwen and Van Essen 2002; Van Klink and Kampf 2005). The animal rights organizations argued that the reserve managers were in contravention of Sect. 36 of the Dutch Animal Health and Welfare Act (Act No. 585 1992), which puts an obligation on "every person" to provide the "necessary care" to animals in need (Tramper 1999), because the reserve fencing effectively led to starvation by preventing animals from migrating to better feeding areas (Tramper 1999; Van Klink and Kampf 2008; Vera 2009). In response to this criticism, the State Forest Service produced ethical guidelines for use by site mangers to guide decisions about when to intervene on animal welfare grounds (Tramper 1999). There is now a policy of "reactive culling" of animals that are considered to be on the brink of death by starvation based on condition monitoring (ICMO 2006; Vera 2009) and best practice guidelines for leaving carcasses in situ have been developed (Tramper 1999).

\section{Costs and Benefits of Leaving Carcasses}

Ecological The availability of deer carcasses in the reserve has benefited scavenging species such as carrion feeding beetles (Van Klink and Kampf 2005) and birds; for example, white-tailed eagles Haliaeetus albicilla now breed successfully in the reserve (Birdlife International 2011). In recognition of these benefits, the Dutch Food and Consumer Product Safety Authority (VWA) recommended running a trial allowing carcasses of the large de-domesticated herbivores to remain in the reserve (Staatsbosbeheer 2012). The VWA believed that there was little risk to public and animal health from doing this (Anon 2010). However, the reserve management strategy for 2011-2015 has retained the principle of removing shot cattle and horses unless the terrain prevents this. Culled red deer on the other hand can remain in situ unless they are a health risk or are likely to reduce people's enjoyment of the reserve (Staatsbosbeheer 2011).

Socio-economic Although concern has been raised over the treatment of animals in the reserve and the implications for disease transmission, there is no evidence that the carcasses left on the reserve have spread disease and subsequently resulted in any economic loss or reduction in the wellbeing of the local community. The main social issue appears to be a conflict of perception between people on how animals should be treated. The distinction between wild and domesticated animals is not clear cut in this situation (Lorimer and Driessen 2013). The State Forest Service-who embraces the notion of re-wilding-does not consider it unethical to leave the carcasses of these populations in the field (Tramper 1999), whilst many visitors and members of the animal rights movement oppose this view and believe they should be removed. However, very little systematic data has been collected, particularly relating to the public's opinion of the management of the Oostvaardersplassen, despite the high profile nature of the case and the court ruling defining heck cattle and Konik ponies as wild animals. Extensive debates over this issue have taken place since the reserve was established (Maris 2009; ICM02 2010).

\section{Case Study 3: Enhancing Scavenger Populations and Communities in the Scottish Uplands (Fig. 1a, b)}

\section{Background}

In some parts of Scotland the carcasses of wild red deer, an iconic species with significant cultural and game value, have been shot during population culls and then placed out or left where they were shot to provide carrion for rare raptors (e.g., golden eagle Aquila chrysaetos and whitetailed eagle), as well as for other perceived biodiversity benefits. Sport shooting of red deer is estimated to contribute US\$ 109.2 million year $^{-1}$ to the Scottish economy (Thomson et al. 2013) and further income is generated from associated tourism and venison production. However, as a large and sometimes numerous herbivore, red deer may damage habitats though overgrazing and trampling (Hunt 2003; Côté et al. 2004). Therefore, cull targets are set in an attempt to balance numbers appropriate for sport hunting with densities appropriate for maintaining good habitat condition. The carcass of a culled animal is generally removed from the hill and sold as venison. As selective culling targets older animals, natural mortality is low (2-3\% adult annual mortality) compared to around $20 \%$ of the population removed through hunting (Armstrong et al. 2012). Therefore, few deer carcasses are naturally available to scavengers. Furthermore, in recent times the switch from CAP-related headage payments to a single farm payment independent of livestock numbers has led to a reduction in the number of sheep and cattle kept in the uplands (Scottish Agricultural College 2008) and therefore a reduction in the number of livestock carcasses that could be available to scavengers. 


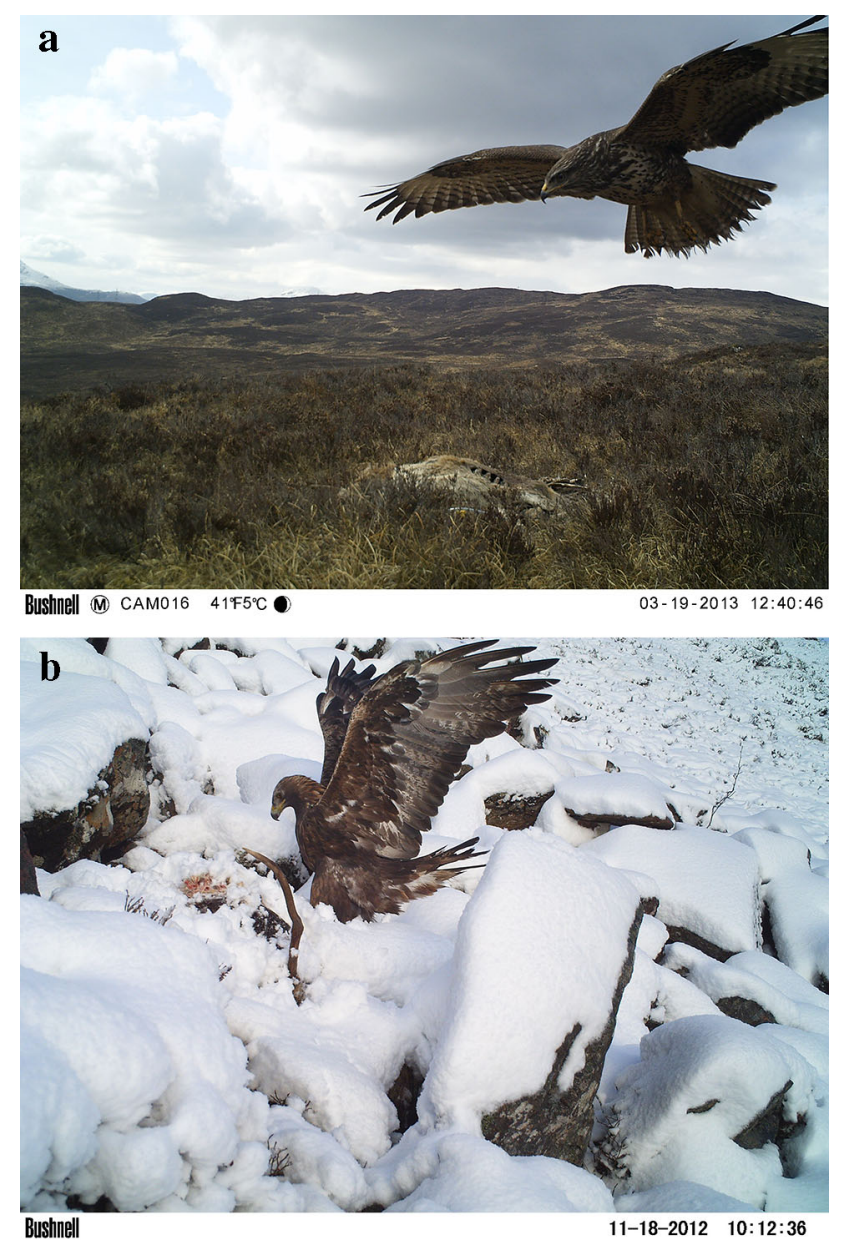

Fig. 1 a Buzzard (Buteo buteo) on deer carcass, Scotland, UK. Credit The James Hutton Institute. b Golden eagle (Aquila chrysaetos) on deer carcass, Scotland, UK. Credit The James Hutton Institute

\section{Motivations for Leaving Carcasses}

There are several motivations for leaving deer carcasses in the uplands. First, some land managers argue that due to a lack of natural predators few carcasses are naturally available to carrion feeders in these areas and they want to reverse this trend (John Muir Trust 2012), also arguing that carcasses will help improve nutrient cycling in these nutrient poor ecosystems (John Muir Trust 2009; Cunningham 2010; John Muir Trust 2012; Trees for Life 2013). Second, carcasses can attract scavengers such as raptors and facilitate wildlife tourism and wildlife photography with its associated economic benefits for rural communities. For example, a golden eagle viewing center has been established, with CCTV cameras focussed on deer carcasses, to allow people to observe these charismatic birds of prey from close by (Wildlife Extra 2008). Third, there is growing interest in the use of carcasses as a mechanism to enhance the populations of specific scavengers such as
Golden Eagles that are listed under Annex I of the Birds Directive and thus regarded as a species of conservation concern (The Scottish Government 2011a; John Muir Trust 2012). This latter motivation has attracted funding from the Scottish Government's Rural Development Programme (SRDP) which pays for deer carcasses to be left out as a food source (The Scottish Government 2011a, b). Although these government incentives do not support culling additional deer over and above pre-determined cull targets, it can provide an incentive to cull deer in remote areas where the cost of extracting carcasses has previously discouraged deer population control. This in turn could help prevent overgrazing in these areas.

\section{The Issues}

Leaving deer carcasses on the hill is legal under Regulation (EC) No 1069/2009 2009 but is highly controversial for three main reasons. First, it is perceived to go against traditional hunting values which assert that shot animals should be respected and utilized, in this case by processing for human consumption. This view is captured by the European Charter on Hunting \& Biodiversity which states that the harvest should be "properly utilised and wastage avoided" (Brainerd 2007). Deliberately leaving deer carcasses on the hill is perceived among many traditional land managers and stalkers as disrespectful, a waste of meat, and a loss of revenue. In addition, there have been situations, where people walking in the hills (a common pastime in Scotland) were distressed to find deer carcasses lying on the land (News group newspapers limited 2011). Such situations have led to organizations using this practice being subjected to negative press coverage and hostility from others (John Muir Trust 2011; Wildlife News 2012). Second, carcasses may attract scavengers, which are, in some cases, also predators of ground nesting birds, including birds of conservation concern (Cortés-Avizanda et al. 2009b) and game birds such as red grouse. Grouse shooting is an important land use, which contributes considerable revenue to the Scottish economy (Game and Wildlife Conservation Trust 2010). To enable this activity, land managers invest substantially in the control of predators such as foxes and crows in order to enhance grouse numbers, however these same species are likely to be attracted to carcasses (Milner et al. 2002) with the side effect that they may predate ground nesting game birds in the vicinity. However, the provision of carcasses could also divert predators away from ground nesting birds by supplying additional feeding opportunities. For example, provisioning hen harriers with chick carcasses reduced predation on red grouse in the Scottish uplands (Redpath et al. 2001). Third, there are concerns that drinking water could be contaminated if carcasses are placed close to 
water courses linked to the public drinking water supply, potentially compromising public health (Milner et al. 2002).

\section{Costs and Benefits of Leaving Carcasses}

Ecological There is little information on the ecological costs or benefits of this practice. However, studies in Scotland and Scandinavia have shown that more carrion feeding beetles (including some species of conservation importance) are found near to deer carcasses compared to control sites (Milner et al. 2002; Melis et al. 2004). Furthermore, vegetation collected near to the carcass was found to have higher nitrogen content than comparable vegetation at a control site (Milner et al. 2002), a finding common to a range of carcass studies conducted elsewhere (Danell et al. 2002; Wilkinson et al. 2005; Melis et al. 2007). Yet, evidence for the benefits of carcasses to target scavenger species is lacking. For example, the effectiveness of carcass placement on golden eagle demography has not been evaluated, even in areas where carcasses have been paid for by SRDP funding (Murray, Pers. comm).

Socio-economic No formal assessments have been made on the socio-economic costs and benefits of leaving carcasses in the Scottish hills. However, one study suggests that it is more cost effective to leave deer carcasses in situ after culling in remote locations rather than extracting them (Milner et al. 2002). However, the practice may not be adopted by estate managers despite the offer of SRDP payments if carcasses lead to a greater perceived need for "pest" or predator control. Indeed, up until March 2012 SRDP funding for this practice has only been taken up by six land managers, at a cost to the Scottish government of $\$ 9500$ (Fraser, pers. comm) although poor uptake may also be due to difficulties with the eligibility criteria, limited financial incentive, and perceived bureaucracy. On the other hand, wildlife tourism, stimulated by providing carcasses to avian scavengers, could bring money into the local economy. For example, the reintroduction of whitetailed eagles to the island of Mull has promoted tourism and provided substantial benefits including employment opportunities in the area (Molloy 2011) although controversy around their reintroduction remains.

\section{DISCUSSION}

The case studies reviewed here suggest that the practice of leaving or placing out carcasses is motivated in most cases by rationales that assume the practice will benefit charismatic species and enable nutrient retention, thereby restoring natural ecosystem functions. This seems intrinsically linked to the notion of re-wilding, and follows a parallel discourse to that of species reintroduction (Arts et al. 2012). Whether carcass placement achieves these objectives remains unclear. However, it is clear that the practice is highly emotive and raises considerable concern due to conflicting beliefs, attitudes, and interests. Thus, when considering this nature conservation practice it is essential to understand the social and economic context, locally and nationally, and address the respective concerns before implementing this controversial practice more widely.

\section{Motivations}

In all three cases (conservation of vultures, re-wilding in the Netherlands, enhancing Scotland's scavenger populations), the underlying motivation for carcass placement seems to be the idea of re-creating or enhancing some of the dynamics that are perceived to be part of "well-functioning" ecosystems. This is centered on the notion that important processes, notably nutrient flow across trophic levels, are impaired, making ecosystems dysfunctional. For some, the aspiration to restore such ecosystem processes is manifested as a desire to "re-wild" the landscape. For example, promoting the merits of abandoned agricultural land for a range of ecosystem functions (Navarro \& Pereira 2012) and enhancing scavenger populations is thereby seen as an essential component of a fully functioning ecosystem. Yet, the practice of placing carcasses, has led to clear and perhaps fairly predictable conflicts, for example on the basis of competing forms of land use in a locality (see White et al. 2009).

Carcass placement has created economic opportunities through eco-tourism and the uptake of funding schemes incentivising the practice of carcass provision. Furthermore, the practice has in some cases allowed carcass extraction and disposal costs to be reduced or eliminated altogether (Scottish deer carcasses and vulture case studies). Diverse biodiversity benefits, ranging from increased abundance of carrion beetles to the formation of large assemblages of vultures have also been identified. However, some of that information is circumstantial (i.e., would white-tailed eagles have started to breed in the Oostvaardersplassen regardless of carcass policies) and the population level benefits of other vertebrate species have not been substantiated.

South West European societies seem to have embraced the practice of leaving carcasses out as a tool to conserve vultures: farmers are happy to provide carcasses, visitors are eager to view the spectacle of vultures feeding, and vultures seem to benefit too. Perhaps the practice is accepted because it is in line with traditional management practices, in which case this could provide a good example 
of the importance of taking traditional land management practices into consideration when suggesting carcass placement as a nature conservation tool.

In other parts of Europe, the placement of carcasses remains an emotive issue. The societal response in the Netherlands is partially linked to the way rules concerning the disposal of carcasses have been implemented leading to a sense of injustice, as farmers are not allowed to leave carcasses out due to bio-security concerns while others may do so in the name of nature conservation. Farmers reinforce this argument by citing the potential for transmission of disease from such carcasses to their domestic livestock and the potential impact on their income and livelihood. In addition, strong feelings, vocalizing the viewpoint that treating domestic animals in this way goes against social norms regarding animal welfare and husbandry has created disputes between those who believe animal rights are being violated and the reserve managers.

In Scotland, the practice of leaving deer carcasses out to benefit the same scavenger species which prey on gamebirds is likely to result in conflict; particularly in areas where traditional game management is a priority and predators such as foxes and crows are controlled in an effort to boost game bird numbers. Those involved in shooting game birds in these areas are concerned that leaving carcasses in situ may indirectly lead to declines in grouse numbers, shooting revenue, and ultimately the loss of rural jobs. In addition, there is the perception that outdoor recreational users may be deterred from visiting areas where there is the prospect of finding dead animals left or placed out in the environment-which was also the case for the Oostvaardersplassen. Whilst these negative impacts are prominent in the discourse over this issue, there is little scientific evidence to inform the debate. The main evidence for a direct effect of carcass placement on large scavengers comes from the SW European case study where vulture numbers increased to high local densities; this affected behavioral characteristics and community composition, adversely leading to increased predation on other species of conservation concern and creating a conflict between differing conservation policy objectives.

\section{Existing Knowledge and the Current Debate}

Although there are many studies that have looked at the effect of carcass placement on soils, plants, and invertebrates, few studies address the role carcasses may play in ecosystem functions such as nutrient cycling within ecosystems or the benefits to charismatic scavenging species, despite these factors being strong and persistent rationales for carcass placement. To not explicitly investigate the influence of carcasses on the population dynamics of those scavengers that are meant to benefit from them but instead focus on more easily studied aspects, such as the localized increase in invertebrate populations or changes in plant nutrients, seems inappropriate and clearly needs to be redressed.

Importantly, the current debate is centered on people's beliefs about nature, which are partially shaped by cultural traditions. In fact, even the motivation to place carcasses to "enhance nutrient cycling" may best be interpreted as an indicator of beliefs about "naturalness" or "how nature ought to be" (Fischer and van der Wal 2007). Therefore, to be able to interpret attitudes toward carcass placement across society, there is a need to understand the deeper motivations and how these are culturally embedded. For example, allowing carcasses to remain within the Oostvaardersplassen went against traditional livestock management and (Dutch) society seems to have struggled to adapt to this challenge. However, this view is likely to have been strongly influenced by the perceived neglect which led to the animals (within a ring-fenced area) starving to death in the first place highlighting the differential beliefs about animal welfare. In Scotland, the controversy over carcass placement may be based on issues relating to the societal norms around treatment of carcasses for venison production and the idea of not wasting meat. By contrast, the vulture case study illustrates that the general acceptance of carcass placement for vulture conservation may be due to the historical use of the "muladares" (places where farmers traditionally brought dead livestock to be cleared away by vultures) prior to the implementation of carcasses disposal restrictions following the BSE outbreak. Thus, in some areas it may be possible to avoid these conflicts by aligning conservation planning with traditional land management practices.

\section{Application}

We have shown that there is little knowledge on the main target species that carcass placement is supposed to benefit, i.e., the large avian and mammalian scavengers; yet it is these species and their impacts which generate much of the discussion in the carcass placement debate. Therefore, in order to inform the conflicts over this strategy and the associated aims to restore or re-wild certain areas, we need to not just better understand the ecological consequences but, perhaps more importantly, pay attention to how the public perceive this practice and the consequences for other legitimate land uses in carcass placement areas.

In conclusion, all the case studies illustrate that expecting carcasses to simply be "good for biodiversity" may be too naïve a view. Although carcasses undoubtedly represent feeding opportunities for a variety of species (Selva et al. 2003; Cortés-Avizanda et al. 2009a) and lead to increases in local abundances, they can also lead to conflicts because of unintended consequences for social 
and economic objectives as well as other ecological impacts. We propose that conservation planning should be clear about its objectives and put in place monitoring to evaluate its success but equally importantly, the aims of carcass placement should be screened against any existing objectives, attitudes, and values of the people living, working, and visiting the areas where carcass placement is proposed. The viability of this tool for use more widely in nature conservation, including its potential role in re-wilding, will only be achieved when we have a greater understanding of the impact of carcass placement on both biodiversity and society as a whole.

Acknowledgments The Authors would like to thank Robin Pakeman for making valuable comments on an earlier version of this manuscript.

\section{REFERENCES}

Act No. 585. 1992. Dutch animal health and welfare act (Genzondheids-en welzijnswet voor dieren).

Anon. 2010. Carcasses of large grazers in nature reserves almost no risk. Abbreviated and translated press release.

Armstrong, H., S. Bathgate, and P. Handley. 2012. The Forest Research red deer population dynamics model: User manual for deer model v3.-1ph + ha2008.xls. Forest Research.

Arts, K., A. Fischer, and R. van der Wal. 2012. Reintroducing charismatic species to Scotland: The rhetoric and politics of a 21st century agenda. ECOS 33: 61-67.

Auduin bird tours. 2012. El Ports Nature Park. Retrieved 6 December, 2012, from http://www.audouinbirding.net/index. php?id=elsportsmountains.

Barton, P.S., S.A. Cunningham, B.C.T. Macdonald, S. McIntyre, D.B. Lindenmayer, and A.D. Manning. 2013a. Species traits predict assemblage dynamics at ephemeral resource patches created by carrion. PLOS ONE 8: 1-9.

Barton, P.S., S.A. Cunningham, D.B. Lindenmayer, and A.D. Manning. 2013b. The role of carrion in maintaining biodiversity and ecological processes in terrestrial ecosystems. Oecologia 171: 761-772.

Bird watching Bulgaria. 2008. Spring intensive birdwatching tour. Retrieved 15 March, 2013, from http://birding.bg/springintensive-birdwatching-tour/.

Birdlife International. 2011. Rewilding may offer a sustainable alternative to traditional management. Presented as part of the BirdLife state of the world's birds website. Retrieved 16 November, 2012, from http://www.birdlife.org/datazone/sowb/casestudy/415.

Blanco, G., J.A. Lemus, and M. García-Montijano. 2011. When conservation management becomes contraindicated: Impact of food supplementation on health of endangered wildlife. Ecological Applications: A Publication of the Ecological Society of America 21: 2469-2477.

Brainerd, S. 2007. European charter on hunting and biodiversity, Bern convention document TPVS revised, 29 November 2007. Strasbourg. Retrieved 19 March, 2013, from http://www.cicwildlife.org/fileadmin/Press?Technical_Series?EN/2_EN.pdf.

Carter, D.O., D. Yellowlees, and M. Tibbett. 2007. Cadaver decomposition in terrestrial ecosystems. Die Naturwissenschaften 94: 12-24.

Commission regualtion (EU) No 142/2011. 2011. Commission regulation (EU) No 142/2011 of 25 Feb 2011 implementing regulation (EC) No 1069/2009 of the European Parliament and of the Council laying down health rules as regards animal byproducts and derived products not intended for human consumption.

Cortés-Avizanda, A., N. Selva, M. Carrete, and J.A. Donázar. 2009a. Effects of carrion resources on herbivore spatial distribution are mediated by facultative scavengers. Basic and Applied Ecology 10: $265-272$.

Cortés-Avizanda, A., M. Carrete, D. Serrano, and J.A. Donázar. $2009 \mathrm{~b}$. Carcasses increase the probability of predation of ground-nesting birds: A caveat regarding the conservation value of vulture restaurants. Animal Conservation 12: 85-88.

Cortés-Avizanda, A., M. Carrete, and J.A. Donázar. 2010. Managing supplementary feeding for avian scavengers: Guidelines for optimal design using ecological criteria. Biological Conservation 143: 1707-1715.

Côté, S.D., T.P. Rooney, J. Tremblay, C. Dussault, and D.M. Waller. 2004. Ecological impacts of deer overabundance. Annual Review of Ecology Evolution and Systematics 35: 113-147.

Cunningham, P. 2010. Part 2 of presentation given at the reforesting Scotland annual meeting at Torridon village hall on 25th September 2010. Retrieved 19 March, 2013, from http://www. wrft.org.uk/files/refertilising $\% 20$ scotland $\% 2027 \% 20$ sept $\%$ $202010 \% 20 \% 5$ BC.

Danell, K., D. Berteaux, and K.A. Bråthen. 2002. Effect of muskox carcasses on nitrogen concentration in tundra vegetation. Arctic 55: 389-392.

DeAngelis, D.L. 1992. Dynamics of nutrient cycling and food webs. London: Chapman \& Hall.

Devault, T.L., O.E. Rhodes, and J.A. Shivik. 2003. Scavenging by vertebrates: Behavioral, ecological, and evolutionary perspectives on an important energy transfer pathway in terrestrial ecosystems. Oikos 2: 225-234.

Dupont, H., J. Mihoub, S. Bobbé, and F. Sarrazin. 2012. Modelling carcass disposal practices: Implications for the management of an ecological service provided by vultures. Journal of Applied Ecology 49: 404-411.

Fischer, A., and R. van der Wal. 2007. Invasive plant suppresses charismatic seabird-The construction of attitudes towards biodiversity management options. Biological Conservation 135: 256-267.

Gilbert, M., R.T. Watson, S. Ahmed, M. Asim, and J.A. Johnson. 2007. Vulture restaurants and their role in reducing diclofenac exposure in Asian vultures. Bird Conservation International 17: 63-77.

Goosney, D. 2008. Vulture feeding stations provide a good opportunity for viewing birds. Retrieved 15 March, 2013, from http:// www.birdguides.com/webzine/article.asp? $\mathrm{a}=1297$.

Groom, M.J., G.K. Meffe, and C.R. Carroll. 2006. Principles of conservation biology, 3rd ed. Sunderland, MA: Sinauer Associates Inc.

Game and Wildlife Conservation Trust. 2010. An economic study of grouse moors: An update. A report produced by The Fraser of Allander Institute for the Game \& Wildlife Conservation Trust.

Heinrich, B. 2012. Life everlasting: The animal way of death. Boston, MA: Houghton Mifflin Harcourt.

Hunt, J.F. 2003. Impact of wild deer in Scotland: How fares the public interest? A report for WWF Scotland and RSPB Scotland.

ICM02. 2010. Natural processes, animal welfare, moral aspects and management of the Ostvaardersplassen. A report of the second International Commission on management of the Oostvaardersplassen (ICM02).

ICMO. 2006. Reconciling nature and human interests. A report of the International Committee on the management of large herbivores in the Oostvaardersplassen (ICMO). The Hague/Wageningen, Netherlands, Wageningen UR-WING rapport 018. 
John Muir Trust. 2009. Helping nature heal itself: Understanding everything in the world is "hitched" to something else. JMT Journal 45: 8-9.

John Muir Trust. 2011. Deer management in Glen Nevis. Retrieved 19 March, 2013, from http://www.jmt.org/news.asp?s=2\&cat= Land\&nid=JMT-N10541.

John Muir Trust. 2012. Wildland management standards. Retrieved 18 March, 2013, from http://www.wildlandmanagement.org.uk/ wp-content/uploads/2012/01/JMT_WLMS_Handbook.pdf.

Lorimer, J., and C. Driessen. 2013. Bovine biopolitics and the promise of monsters in the rewilding of Heck cattle. Geoforum 48: $249-259$

Margalida, A., and M.À. Colomer. 2012. Modelling the effects of sanitary policies on European vulture conservation. Scientific reports 2: 753 .

Margalida, A., J.A. Donázar, M. Carrete, and J.A. Sánchez-Zapata. 2010. Sanitary versus environmental policies: Fitting together two pieces of the puzzle of European vulture conservation. Journal of Applied Ecology 47: 931-935.

Margalida, A., D. Campion, and J.A. Donázar. 2011. Scavenger turned predator: European vultures' altered behaviour. Nature 480: 457.

Maris, E. 2009. Reflecting the past. Nature 462: 30-32.

Martín-Vega, D., and A. Baz. 2011. Could the "vulture restaurants" be a lifeboat for the recently rediscovered bone-skippers (Diptera: Piophilidae)? Journal of Insect Conservation 15: 747-753.

Melis, C., I. Teurlings, J.D.C. Linnell, R. Andersen, and A. Bordoni. 2004. Influence of a deer carcass on Coleopteran diversity in a Scandinavian boreal forest: A preliminary study. European Journal of Wildlife Research 50: 146-149.

Melis, C., N. Selva, I. Teurlings, C. Skarpe, J.D.C. Linnell, and R. Andersen. 2007. Soil and vegetation nutrient response to bison carcasses in Białowieża Primeval Forest, Poland. Ecological Research 22: 807-813.

Milner, J., J. Alexander, and C. Griffin. 2002. A highland deer herd and its habitat. London: Red Lion House.

Molloy, D. 2011. Wildlife at work. The economic impact of whitetailed eagles on the Isle of Mull. Sandy, UK: The RSPB.

Moreno-Opo, R., A. Margalida, F. García, Á. Arredondo, C. Rodríguez, and L.M. González. 2012. Linking sanitary and ecological requirements in the management of avian scavengers: Effectiveness of fencing against mammals in supplementary feeding sites. Biodiversity and Conservation 21: 1673-1685.

Navarro, L.M., and H.M. Pereira. 2012. Rewilding abandoned landscapes in Europe. Ecosystems 15: 900-912.

News group newspapers limited. 2011. Horror at deer cull. Retrieved 19 March, 2013, from http://www.thesun.co.uk/sol/homepage/ news/scottishnews/3389869/Horror-at-deer-cull.html.

Piper, S.E. 2005. Supplementary feeding programmes: How necessary are they for the maintenance of numerous and healthy vulture populations? In Proceedings of the international conference on conservation and management of vulture populations (pp. 41-50). Thessaloniki: Natural History Museum of Crete and WWF Greece.

Redpath, S.M., S.J. Thirgood, and F.M. Leckie. 2001. Does supplementary feeding reduce predation of red grouse by hen harriers? Journal of Applied Ecology 38: 1157-1168.

Regulation (EC) No 1069/2009. 2009. Regulation (EC) No 1069/2009 of the European Parliament and of the Council of 21 October 2009 laying down health rules as regards animal by-products and derived products not intended for human consumption and repealing regulation (EC) No 1774/2002.

Regulation (EC) No 1774/2002. 2002. Regulation (EC) No 1774/2002 of the European Parliament and of the Council of 3 October 2002 laying down health rules concerning animal by-products not intended for human consumption.
Regulation 2005/830/EC. 2005. Regulation 2005/830/EC: Commission decision of 25 November 2005 amending decision 2003/322/EC as regards the feeding of certain necrophagous birds with certain category 1 material (notified under document number C(2005) 4521).

Scottish Agricultural College. 2008. Farming retreat from the hills. Retrieved 14 March, 2013, from http://www.sruc.ac.uk/ downloads/file/28/farming_s_retreat_from_the_hills-full_report.

Selva, N., B. Jedrzejewska, and W. Jedrzejewski. 2003. Scavenging on European bison carcasses in Bialowieza Primeval Forest (eastern Poland) 1. Ecoscience 10: 303-311.

Selva, N., B. Jedrzęjewska, W. Jedrzęjewski, and A. Wajrak. 2005. Factors affecting carcass use by a guild of scavengers in European temperate woodland. Canadian Journal of Zoology 83: $1590-1601$.

Staatsbosbeheer. 2011. Managementplan Oostvaardersplassengebied 2011-2015. Staatsboseheer. Retrieved 25 March, 2013, from http:// www.rijksoverheid.nl/documenten-en-publicaties/jaarplannen/ 2011/05/17/managementplan-oostvaardersplassengebied2011-2015.html.

Staatsbosbeheer. 2012. FAQ. Retrieved 27 November, 2012, from http://www.staatsbosbeheer.nl/English/Oostvaardersplassen/ FAQ.aspx.\%20.

The Scottish Government. 2011a. Supplementary food provision for raptors. Retrieved 19 March, 2013, from http://www.scotland. gov.uk/Topics/farmingrural/SRDP/RuralPriorities/Options/Food ProvisionForRaptors.

The Scottish Government. 2011b. Grant rates for axis 2 options. Retrieved 19 March, 2013, from http://www.scotland.gov.uk/ Topics/farmingrural/SRDP/RuralPriorities/RPACPaymentRate/ Axis2Rates.

Thomson, K., A. McKee, B. Slee, and J. Irvine. 2013. A methodology for assessing the public interest of economic impacts of deer management. Report to Scottish Natural Heritage.

Towne, E.G. 2000. Prairie vegetation and soil nutrient responses to ungulate carcasses. Oecologia 122: 232-239.

Tramper, R. 1999. Ethical guidelines: Guidelines for dealing with self-reliant animals on land managed by the State Forest Service. Utrecht: Centre for Bioethics and Health Law University of Utrecht.

Trees for Life. 2013. Carrion. Retrieved 19 March, 2013, from http:// www.treesforlife.org.uk/forest/ecological/carrion.html\%20.

Van Klink, E.G.M., and I.H. Kampf. 2008. Implementing veterinary and animal welfare regulations in semi-natural pastoral landscapes in the Netherlands. Ministry of Agriculture, Nature and Food Quality, Knowledge Directorate.

Van Klink, E.G.M., and I.H. Kampf. 2005. Experiences in veterinary law with large scale grazing projects in the Netherlands? National approach and European dimension. Retrieved 16 November, 2012, from http://www.grazingnetworks.nl/grazing-and-grazinganimals/veterinary-issues/experiences-in-veterinary-law.

Van Leeuwen, J.M., and G.J. Van Essen. 2002. Health risks between large herbivores, farm animals and man. Vakblad Natuubeheer English edition 41: 37-39.

Vera, F.W.M. 2009. Large-scale nature development-The Oostvaardersplassen. British Wildlife 20: 28-36.

White, R.M., A. Fischer, K. Marshall, J.M.J. Travis, T.J. Webb, S. di Falco, S.M. Redpath, and R. van der Wal. 2009. Developing an integrated conceptual framework to understand biodiversity conflicts. Land Use Policy 26: 242-253.

Whitfield, D.P., A.H. Fielding, D.R.A. McLeod, and P.F. Haworth. 2008. A conservation framework for golden eagles: Implications for their conservation and management in Scotland. Scottish Natural Heritage commissioned report No. 193 (ROAME No. F05AC306). 
Wildlife Extra. 2008. New golden eagle viewing scheme launched in Scotland. Retrieved 19 March, 2013, from http://www. wildlifeextra.com/go/news/golden-eagles_scotland.html\#cr.

Wildlife News. 2012. Dead deer litter Glen Nevis. Retrieved 19 March, 2013, from http://wildlifenews.co.uk/2011/dead-deerlitter-glen-nevis/.

Wilkinson, C.E., M.D. Hocking, and T.E. Reimchen. 2005. Uptake of salmon-derived nitrogen by mosses and liverworts in coastal British Columbia. Oikos 108: 85-98.

Wilmers, C.C., R.L. Crabtree, D.W. Smith, K.M. Murphy, and W.M. Getz. 2003. Trophic facilitation by introduced top predators: Grey wolf subsidies to scavengers in Yellowstone National Park. Journal of Animal Ecology 72: 909-916.

Wilson, E.E., and E.M. Wolkovich. 2011. Scavenging: How carnivores and carrion structure communities. Trends in Ecology \& Evolution 26: 129-135.

Zuberogoitia, I., J.E. Martínez, A. Margalida, I. Gómez, A. Azkona, and J.A. Martínez. 2010. Reduced food availability induces behavioural changes in Griffon Vulture Gyps fulvus. Ornis Fennica 87: 52-60.

\section{AUTHOR BIOGRAPHIES}

Debbie Fielding $(\bowtie)$ is a researcher at the James Hutton Institute, Aberdeen, with a specific interest in the way land management affects ecological communities.
Address: The James Hutton Institute, Craigiebuckler, Aberdeen AB15 $8 \mathrm{QH}, \mathrm{UK}$.

e-mail: debbie.fielding@hutton.ac.uk

Scott Newey is a postdoctoral researcher at the James Hutton Institute, Aberdeen, Scotland with an interest in population ecology and wildlife management, particularly of game and hunted species and those species affected by game management.

Address: The James Hutton Institute, Craigiebuckler, Aberdeen AB15 $8 \mathrm{QH}, \mathrm{UK}$

Address: Faculty of Applied Ecology, Hedmark University College, Evenstad, 2480 Koppang, Norway.

René van der Wal is a Reader at the University of Aberdeen with a specific interest in nature conservation and thereby people's roles in the ecology of a place.

Address: Aberdeen Centre for Environmental Sustainability, School of Biological Sciences, University of Aberdeen, Aberdeen AB24 3UU, UK.

R. Justin Irvine is a principle scientist at the James Hutton Institute, Aberdeen, Scotland and honorary senior lecturer at the University of Aberdeen. His interests lie in natural resource management and the interaction between people and the environment.

Address: The James Hutton Institute, Craigiebuckler, Aberdeen AB15 $8 \mathrm{QH}, \mathrm{UK}$ 